\title{
- caos havia se instalado. Vamos agora vencê-lo
}

\begin{abstract}
Quando cheguei ao Ministério da Administraçăo, vi instalado o caos. Uma parafernália típica de uma era de concentraçāo de poderes e de pulverizaçăo de deveres - toda espécie de distorçāo das leis e dos regulamentos que regem a vida do servidor público brasileiro.
\end{abstract}

Presidente José Sarney, em boa hora, sentindo a necessidade de instrumentar essa área vital para o desenvolvimento nacional. autorizou-me a transformar o caos numa ordenaçăo democrática, transparente $\mathbf{e}$ eficaz. Enfim, determinou que recriássemos a máquina administrativa do Governo Federal, através de uma reforma conceitual e institucional no serviço público brasileiro.

Co politico antigo jornalista político e Constituinte, entendo que nenhum esforço pode gerar resultados se năo for comunicado. Tenho a noçāo constante da necessidade de informaçāo dos atos praticados pelo Governo, para que a sociedade e a opiniāo pública sejam constante esclarecidas sobre a açāo pública.

Chegei ao recém-criado ministério com a idéia fixa de organizar um mutirāo intelectual, reunindo toda a inteligência do Pais no dominio da Administraçāo. da Economia e das Finanças, do Direito Público e até das Ciências Sociais, para emprestar seu talento e sua capacidade indagativa à Reforma Administrativa que iniciamos. Conseguimos já, nesses primeiros meses, avançar o suficiente para remover um pouco do caos, e divisarmos a luz.
Ao final dessa primeira etapa, já temos muito a comunicar, de resultados efetivos dos estudos das Câmaras em que se dividiu a Comissāo Geral da Reforma Administrativa, nomeada por decreto pelo Presidente da República. O País foi percorrido, de Sul a Norte, pela idéia da reforma e da mudanca de métodos de administrar a coisa pública. na forma de seminários. painéis, reuniōes de trabalho, e debates através de poderosos meios eletrônicos, como o sistema

de TV-Fxecutiva da Embratel.

$\mathrm{O}$ centro de convergência de todo esse esforço foi situado na Fundaçâo Centro de Formaçāo do Servidor Público, FUNCEP, uma instituiçāo modelar, que hoje leva ao pé da letra o compromisso de aperfeiçoar. treinar, adaptar e estimular a categoria do funcionalismo público brasileiro.

\begin{abstract}
A Reforma Administrativa nāo poderia prescindir de um veículo de difusāo capaz de dimensionar as grandes linhas de estudos e debates sustentados nas reuniōes e seminários. Toda essa experiência intelectual. de troca democrática de idéias vem criando um patrimônio de reforma que nāo deve ser desperdiçado. Nossa função é a de implementar a Reforma Administrativa no presente, mas também de legar para o futuro, para as geraçōes de estudiosos e executivos da administraçầo pública que nos sucederem. um acervo vivo de mudanças.
\end{abstract}

Por isso tudo, pensei, logo nos primeiros dias da tarefa 


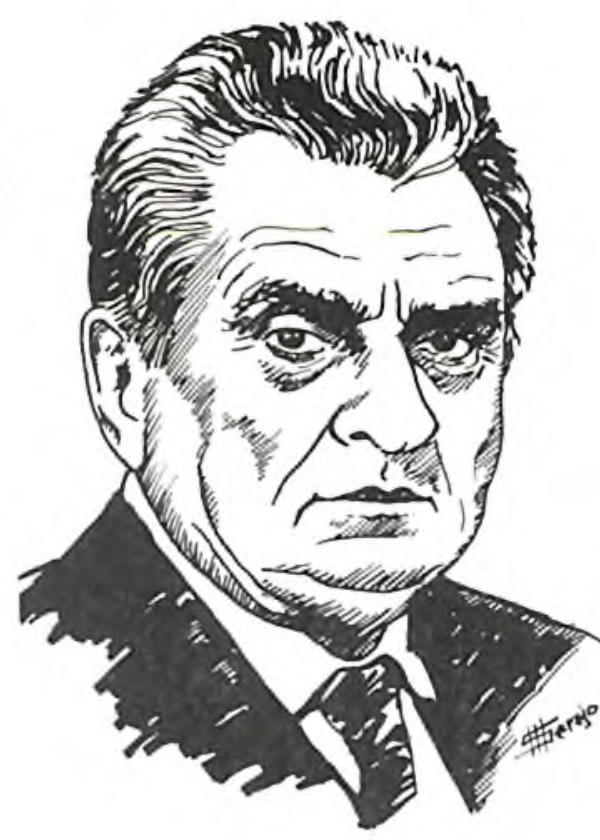

\section{6}

A Reforma, como disse o Presidente
José Sarney, está na cabeca de cada um
de nós. Portanto, vamos complementá-la,
através de um esforco comum, comecando
por incorporar a visão de que a Reforma
é nossa, para melhorar a vida de
cada um de nós, que atuamos no
Servico Público. Este é o desafio,$~$

recelida do Presidente José Sarney, reviver um marco intelectual do serviço público braileiro, coluna do pensamento e das experiências práticas sobre a administraçāo governamental. Com 42 anos de existência, a REVISTA DO SERVICO PÜLICO precisava voltar urgentemente a circular, para trazer a nós todos uma visāo das transformaçōes que o $\mathrm{Pais}$ vive nessa quadra de reformas.

Editada pela FUNCEP, a Fundaçāo Centro de Formaçâo do Serviço Público, que é o verdadeiro lastro da Reforma Administrativa, a revista tradicional volta agora com nova roupagem, novos conceitos editoriais, preservando embora a sua tipica mensagem, sua caracteristica de veículo de difusāo de estudos e debates. Articulistas de todas as categorias de pensamento foram convidados por nosso corpo editorial a fazer parte dessa ediçâo de relançamento da Revista. Sâo os quadros intelectuais que integram a ComissāoGeral da Reforma
Administrativa, e que emprestam o brilho de seu talento e discortinio à produção de uma Revista voltada para a informaçāo e para a formaçāo.

O desafio é superior. Mas tanto quanto aceitamos levar à frente a Reforma Administrativa, também nāo vacilamos em reeditar a Revista, sob novos padrōes visuais e conceituais. $O$ recheio é o mesmo: a ciência da administraçăo pública como fundo de contribuiçăo para estudiosos,

pesquisadores, executivos públicos, administradores $e$ todos quanto tomam decisōes em nosso Pais. E, como forma, imaginamos oferecer também um produto editorial mais comunicativo com o leitor, mais jornalistico e atrativo

Eis a nova fase da REVISTA DO SERVICO PÜBLICO, que espelhará em última análise o corpo vivo da reforma. Uma coisa estará associada à outra: a revista será o órgāo de divulgaçāo mais nobre da Reforma Administrativa do Governo Federal, atribuida à responsabilidade do Ministério da Administraçāo.
Nosso desejo é de que o leitor tire o integral proveito, e que mantenha com a Redacāo da Revista um permanente vinculo, para nos trazer sugestōes. críticas, idéias e argumentos novos. Nossa seçăo de cartas do Leitor, no próximo número será uma das mais prestigiadas, dentro do espirito de transparência $\mathrm{e}$ estimulo à par ticipaçāo, que nossa tarefa requer.

$\mathrm{Na}$ verdade, sem uma mudança de ordem conceitual, para situar a importância da adesăo de tidos à idéia da reforma, nada se conseguirá. Parafraseando o Presidente José Sarney, a reforma está na cabeça de cada um de nós. Portanto, vamos complementá-la, através de um esforco comum. comecando por incorporar a visāo de que a Reforma é nossa, para melhorar a vida de cada um de nós que atuamos no Serviço Público. Que a Revista possa refletir com clareza essa transcedental responsabilidade a nós confiada.

Aluízio Alves 